\title{
Yükselen Piyasa Ekonomilerinde Menkul Kıymetler Borsalarının Entegrasyonu: Türkiye ve BRICS Ülkeleri Üzerine Çoklu Yapısal Kırılmalı Eş-bütünleşme Analizi*
}

\author{
Şerife ÖZŞAHIN***
}

\begin{abstract}
$\ddot{O} Z$
1990 'l yllarda hayata geçirilen finansal liberalizasyon politikalarl, sermaye hareketliliğinin önüne engel oluşturan pek çok uygulamanın terkedilmesine yol açmıştır. Bu doğrultuda finansal işlemler, ulusal para ve sermaye piyasalarının ötesine taşınmiş ve ülkelerin diş dünyaya entegrasyon seviyesinde artı̧̧ gözlenmiştir. Ancak entegrasyon düzeyindeki bu artı̧̧, ülkelerden birinde ortaya çıkacak bir sorunun diğer ülkelere de yansımasına neden olmuş ve özellikle yükselen piyasa ekonomilerinin menkul klymetler borsalarinda benzer hareketler ortaya çıkmıştır. Bu çalışmada BRICS ülkeleri olarak adlandırılan Brezilya, Rusya, Hindistan, Çin ve Güney Afrika ile Türkiye'nin borsa endeksleri arasında eşzamanlı hareketlenmenin olup olmadiğ araştırlmaktadır. Bu amaçla, bu ülkelere ait 2000-2016 dönemi aylık MSCI Yükselen Piyasalar Endeksi kullanılarak Carrion-i-Silvestre (2009) çoklu yapısal kırllmalı birim kök testi ve Maki (2012) çoklu yapısal kırılmalı eş-bütünleşme testleri ile ekonometrik analiz yapılmıştır. Analiz sonucunda Brezilya haricindeki diğer dört ülkenin menkul klymetler borsası ile Türkiye BIST borsasinın uzun dönemde birlikte hareket ettiği bulgusuna ulaşılmıştır. FMOLS ve DOLS modellerinin uzun dönem katsayı tahmin sonuçları ise Türkiye ile Rusya, Hindistan, Çin, Güney Afrika borsa endeksleri arasında uzun dönemde pozitif ve \%99 önem düzeyinde istatistiksel olarak anlamlı iliş̧ilerin mevcut olduğunu ortaya koymaktadır. Bu sonuca dayanarak uzun dönemde bu ülke borsaları arasında risk çeşitlendirmesi yapmanın mümkün olmayacağ yapılabilecektir.
\end{abstract}

Anahtar Kelimeler: MSCI Yükselen Piyasalar Endeksi, BRICS, Türkiye, Çoklu Yapısal Kırılmalı Birim Kök ve Eş-bütünleşme Testleri

JEL Sinıflandırması:E44, F36, G15, C22

International Stock Market Connection in Emerging Markets: Cointegration Analyses with Multiple Structural Breaks on Turkey and BRICS Countries

\begin{abstract}
Financial liberalization policies that were put into practice in the 1990 s led to the renouncement of many practices which prevented capital mobility. In this respect, financial transactions were carried beyond the national money and capital markets, and an increase in the integration level of countries was observed. However, this increase in the level of integration led a problem that could occur in a country to reflect on other countries; and thus, similar movements were observed particularly in the stock markets of the emerging market economies. This study examines whether there has been a simultaneous movements between the stock indexes of Brazil, Russia, India, China and South Africa, which are known as BRICS countries, and Turkey. To this

\footnotetext{
* Bu çalışma, ICPESS-2017'de sözlü sunumu yapılan “International Stock Market Connection: Evidence from Turkey and BRICS Countries" başlıklı bildirinin geliştirilmiş şeklidir.

${ }^{* *}$ Yrd.Doç.Dr., Necmettin Erbakan Üniversitesi, SBBF, İktisat Bölümü, sozsahin@konya.edu.tr
} 
end, using the monthly MSCI emerging market index for these countries for the 2000-2016 period, an econometric analysis was conducted with the Carrion-i-Silvestre (2009) multiple structural breaks unit root test and Maki (2012) multiple structural breaks co-integration tests. The analyses revealed that the stock markets of the BRICS countries except for Brazil and the stock market of Turkey act together in the long term. The long-term coefficient estimation results of FMOLS and DOLS models indicated that there has been a long-term positive relationship between the stock indexes of Turkey and Russia, India, China, and South Africa at 99\% significance level. Based on this result, it can be stated that it may not be possible to make risk diversification between the stock markets of these countries in the long term.

Key Words: MSCI Emerging Market Index, BRICS, Turkey, Multiple Structural Breaks Unit Root and Co-integration Tests

JEL Classification: E44, F36, G15, C22

\section{GİRIŞ}

Ulusal finans piyasalarının uluslararası finansal piyasalarla bütünleşmesi anlamına gelen finansal küreselleşme, hükümetlerin yurtiçi finans sektörü üzerindeki kontrollerini kaldırması ve sermaye işlemleri hesabını liberalize etmeye yönelik uygulamalarını kapsamaktadır (Schmukler, 2008: 48). 1980'li yılların ortalarında başlayan finansal bütünleşme dalgası, sermayenin gelişmiş ülkeler ve gelişmekte olan ülkeler arasında hiçbir kısıtlama olmaksızın hareket etmesine imkan tanımıştır. Bilgi ve iletişim teknolojilerindeki yenilikler neticesinde finansal işlemlerin dünya çapında yapılabilir olması, sermayenin bol olduğu ülkelerden kıt olduğu ülkelere doğru hareketinin önünde herhangi bir engel kalmamasına yol açarak tasarrufların global ölçekte daha etkin dağılmasını sağlamıştır (Driessen ve Laeven, 2003: 176). Bunun yanı sıra finansal enstrüman sayısındaki artış da yabancı yatırımcılara risk çeşitlendirmesi yapma firsatı sunarak finansal liberalleşme hareketlerinin ivme kazanmasına yardımcı olmuştur (Eichengreen ve Mussa, 1998: 16-17).

Serbest dolaşım imkanına kavuşan yabancı sermaye, kendine en yüksek getiriyi sağlayan piyasaların arayışı içine girmiştir. Sermayenin, getirisinin yüksek ve kıt olduğu gelişmekte olan ülkelere yönelmesi, bu ülkelerde finansal kaynak miktarını artırmıştır (Schmukler, 2008). Ayrıca piyasalar hakkındaki fiyat ve getiri bilgilerinin tüm piyasa aktörleri tarafından aynı anda edinilmesi de fiyat farklılığından hareketle arbitraj getirisi elde etme imkanını ortadan kaldırmaktadır. $\mathrm{Bu}$ doğrultuda finans piyasaları arasındaki bütünleşme derecesinin artması ile piyasalar arasında tek fiyat kanunu geçerli olacak ve fiyat farklılığından dolayı kazanç sağlama imkanı olmayacaktır.

Gerek ticari gerekse de finansal açıdan daha entegre olan ülkelerin birinde ortaya çıkacak bir şokun diğer ülkeleri de etkisi altına alması hisse senedi piyasalarında benzer hareketlerin gözlenmesine neden olmuştur. Bu doğrultuda özellikle 2000'li yıllardan sonra menkul kıymetler borsalarının uzun vadede benzer eğilimler göstermesi, bu ilişkinin ampirik açıdan test edilmesi amacıyla yapılan çalışmaların sayıca artmasına yol açmıştır. Yapılan çalışmalarda ABD, AB gibi gelişmiş ülke borsaları arasındaki etkileşim, ASEAN, MENA, GCC gibi gelişmekte olan ülke borsaları arasındaki etkileşim veya gelişmiş ülke borsa 
endekslerinin gelişmekte olan ülke borsaları üzerine etkisi araştırılmıştır (Berument vd., 2011: 85).

$\mathrm{Bu}$ çalışmada Türkiye ve BRICS ülkeleri borsa endekslerinin uzun dönemde aynı yönde hareket edip etmediği bir diğer ifadeyle borsa endeksleri arasındaki eş-bütünleşme ilişkisi araştırılmaktadır. Bu amaçla Morgan Stanley Capital International (MSCI) yükselen piyasalar borsa endekslerinin Ocak 2000Aralık 2016 dönemi ABD doları cinsinden günlük kapanış değerleri kullanılarak ekonometrik analiz yapılmıştır. Bu çalışma, Türkiye ve BRICS ülkeleri borsa endekslerinin uzun dönemde birlikte hareket eğilimini çoklu yapısal kırılmaların varlığı altında test etmesi yönüyle ilgili literatüre katkı sağlamaktadır. Kasman vd. (2009), Korkmaz vd. (2009), Yılancı ve Öztürk (2010) yapısal kırılmaların varlığında eş-bütünleşme ilişkisini test etmiş olmakla birlikte bu çalışmalar en fazla iki yapısal kırılmayı dikkate almaktadır. Beş yapısal kırılmaya izin veren birim kök ve eş-bütünleşme testleri ile ekonometrik analiz yapılması, bu çalışmayı mevcut literatürden farklı kılmaktadır.

Giriş bölümünü takiben literatür taraması kısmında menkul kıymetler borsalarının uluslararası düzeyde entegrasyonunu Türkiye'yi dahil ederek araştıran çalışmalar ve edindikleri bulgular özetlenecektir. Üçüncü bölümde veriseti açıklanacak ve değişkenlere ilişkin tanımlayıcı istatistiklere yer verilecektir. Ekonometrik yöntemin tanıtıldığı ve ulaşılan ampirik bulguların yorumlandığı dördüncü bölümün ardından kısa bir değerlendirme ile çalışma sonlandirilacaktır.

\section{LITARATÜR TARAMASI}

Finansal liberalizasyon politikalarının hayata geçirildiği ve ülkelerin entegrasyon düzeyinde artışın gözlendiği 1990'lı yılların ardından sermaye piyasaları arasında benzer hareketlerin varlığını araştıran ampirik çalışmalar yapılmaya başlanmıştır. Bu çalışmada Türkiye ve BRICS ülkeleri sermaye piyasaları arasında entegrasyonun varlığı çoklu yapısal kırılmalı birim kök ve eşbütünleşme yöntemleri ile araştırılmaktadır. $\mathrm{Bu}$ çalışmanın temel inceleme konusu Türkiye menkul kıymetler borsasının diğer ülke borsaları ile eşbütünleşme ilişkisi olduğundan dolayı literatür taraması yapılırken Türkiye'nin de örneklemde yer aldığı çalışmalar üzerinde yoğunlaşılmıştır. Bu çalışmalarda kullanılan yöntemler, örneklemde yer alan ülkeler, incelenen zaman dilimi ve edinilen bulgulara yönelik kısa bir özet Tablo 1'de sunulmaktadır.

Tablo 1. Konuyla İlgili Geçmiş Literatür ve Ulaşılan Bulgular

\begin{tabular}{|c|c|c|}
\hline Çalışma & $\begin{array}{l}\text { Ülke Grubu, Kullanılan Yöntem } \\
\text { ve İncelenen Zaman Dilimi }\end{array}$ & Sonuç \\
\hline Malatyalı (1998) & $\begin{array}{l}\text { - ABD, Kanada, İngiltere, } \\
\text { Almanya, Japonya, Arjantin, } \\
\text { Meksika, Şili, Yunanistan, } \\
\text { Türkiye, Güney Kore, } \\
\text { Tayland, Filipinler } \\
\text { - Dinamik En Küçük Kareler } \\
\text { Yöntemi }\end{array}$ & $\begin{array}{l}\text { Latin Amerika ve Uzak Doğru } \\
\text { Asya ülkelerinin borsa getirileri } \\
\text { arasında eş-bütünleşik ilişki } \\
\text { mevcutken Türkiye ve Yunanistan } \\
\text { arasında böylesi bir ilişkinin } \\
\text { olmadığını belirtmektedir. }\end{array}$ \\
\hline
\end{tabular}


Ş. Özşahin / Yükselen Piyasa Ekonomilerinde Menkul Klymetler Borsalarının Entegrasyonu: Türkiye ve BRICS Ülkeleri Üzerine Çoklu Yapısal Kırılmalı Eş-bütünleşme Analizi

\begin{tabular}{|c|c|c|}
\hline & - $\quad$ Ocak 1986-Haziran 1997 & \\
\hline $\begin{array}{l}\text { Gündüz ve } \quad \text { Omran } \\
(2001)\end{array}$ & 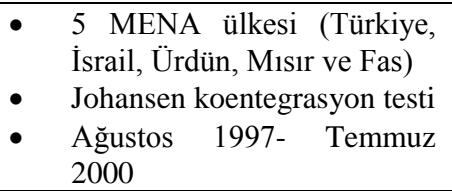 & $\begin{array}{l}5 \text { MENA ülkesinin hisse senedi } \\
\text { piyasaları arasında eş-bütünleşme } \\
\text { ilişkisi bulunamamıştır. }\end{array}$ \\
\hline Maneschiold (2005) & $\begin{array}{l}\text { - } \text { ABD S\&P 500 ile Türkiye } \\
\text { Ulusal } 100 \text { endeksi ve Misır } \\
\text { Cairo Stock Exchange } \\
\text { General Index } \\
\text { - Johansen koentegrasyon testi } \\
\text { - } 9 \text { Ağustos 1999-18 Mart } \\
\text { 2005 }\end{array}$ & $\begin{array}{l}\text { Sanayi sektörü alt endeksi } \\
\text { kullanılarak yapılan analiz eş- } \\
\text { bütünleşmenin olduğuna işaret } \\
\text { ederken, finans ve hizmetler alt } \\
\text { sektörü sonuçlarına göre uzun } \\
\text { dönem ilişkiye rastlanmamıştır. }\end{array}$ \\
\hline Marashdeh (2005) & $\begin{array}{l}\text { - } 4 \text { MENA ülkesinin kendi } \\
\text { aralarında (Mısır, Türkiye, } \\
\text { Ürdün ve Fas) ve gelişmiş } \\
\text { ülke piyasaları (ABD, } \\
\text { İngiltere ve Almanya) ile } \\
\text { ilişkisi } \\
\text { - } \\
\text { - ARDL Sinır Testi } \\
\text { Aralık 1994-Haziran } 2004\end{array}$ & $\begin{array}{l}\text { MENA ülkelerinin her biri arasında } \\
\text { uzun dönem ilişki olmasına } \\
\text { rağmen, Misır dışında kalan diğer } \\
\text { ülkeler ile gelişmiş ülke piyasaları } \\
\text { arasında eş-bütünleşme ilişkisi } \\
\text { ortaya çıkmamıştır. }\end{array}$ \\
\hline Bayri ve Güloğlu (2005) & 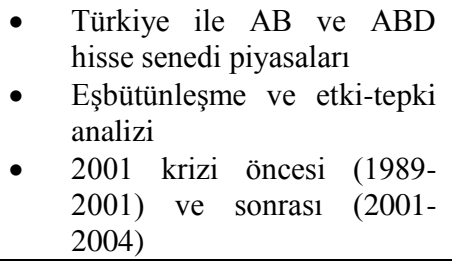 & $\begin{array}{l}\text { Türkiye ile } A B \text { ve } A B D \text { hisse } \\
\text { senedi piyasaları arasında uzun } \\
\text { dönem ilişki vardır. }\end{array}$ \\
\hline $\begin{array}{l}\text { Berument ve İnce } \\
(2005)\end{array}$ & $\begin{array}{l}\text { - Amerika S\&P 500 borsa } \\
\text { endeksi ve Türkiye IMKB } \\
100 \text { endeksi } \\
\text { - Cushman ve Zha (1997) } \\
\text { SVAR modeli } \\
\text { - } 23 \text { Ekim 1987-8 Haziran } \\
2004 \\
\end{array}$ & $\begin{array}{l}\text { Günlük veriler kullanılarak yapılan } \\
\text { analiz sonucunda Amerika S\&P } \\
500 \text { borsa endeksindeki yükselişin } \\
\text { İMKB getirilerini olumlu yönde } \\
\text { etkilediği belirlenmiştir. }\end{array}$ \\
\hline Çıtak ve Gözbaşı (2007) & $\begin{array}{ll}\text { - İMKB ile gelişmiş } \\
\text { ülkelerden ABD, Almanya, } \\
\text { İngiltere, Japonya ve } \\
\text { gelişmekte olan ülkelerden } \\
\text { Hindistan ve Malezya } \\
\text { - Engle-Granger eşbütünleşme } \\
\text { yöntemi } \\
\text { - Ocak 1986-Temmuz } 2006\end{array}$ & $\begin{array}{l}\text { İMKB ile İngiltere, ABD, Almanya } \\
\text { ve Hindistan borsaları arasında } \\
\text { uzun dönemli ilişki vardır. }\end{array}$ \\
\hline Doğan ve Yalçın (2008) & 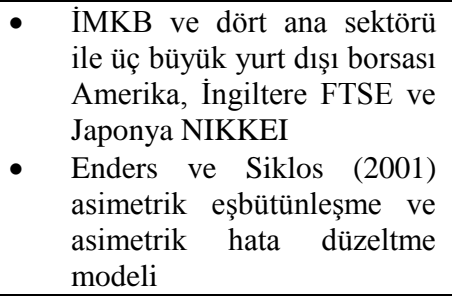 & $\begin{array}{l}\text { Yurtdışı gelişmeler uzun dönemde, } \\
\text { İMKB endeksi ve teknoloji } \\
\text { dışındaki tüm alt sektörlerde } \\
\text { simetrik olmayan bir etki } \\
\text { yaratmaktadır. IMMKB borsas } \\
\text { Amerika DOW ve Japonya } \\
\text { NIKKEI borsalarındaki olumlu } \\
\text { gelişmelere buna karşın Ingiltere }\end{array}$ \\
\hline
\end{tabular}




\begin{tabular}{|c|c|c|}
\hline & $\begin{array}{ll}\text { - } & 2001-2007 \text { dönemine ait } \\
\text { günlük veriler }\end{array}$ & $\begin{array}{l}\text { FTSE borsasındaki olumsuz } \\
\text { gelişmelere daha duyarlıdır. }\end{array}$ \\
\hline $\begin{array}{l}\text { Sevüktekin ve } \\
\text { Nargeleçekenler(2008) }\end{array}$ & $\begin{array}{ll}\text { - } & \text { Amerika borsalar1 Dow } \\
\text { Jones, Nastaq, SP500 ile } \\
\text { Türkiye IMKB borsas1 } \\
\text { - } \quad \text { Johansen eşbütünleşme } \\
\text { - } 1986-2007 \text { arası aylik veriler }\end{array}$ & $\begin{array}{l}\text { Uzun dönemde Amerika borsalar } \\
\text { IMKB üzerinde pozitif ve anlamlı } \\
\text { etkilere sahiptir. IMKB üzerinde en } \\
\text { büyük etkiyi DowJones } \\
\text { yapmaktadır. Ayrıca uzun dönemde } \\
\text { çift yönlü nedensellik varken kısa } \\
\text { dönemde Amerika borsalarından } \\
\text { IMKB'ye doğru nedensellik vardır. }\end{array}$ \\
\hline Kasman vd. (2009) & $\begin{array}{l}\text { - } \text { Türkiye, Fransa, Japonya, } \\
\text { İngiltere, ABD, Almanya, } \\
\text { Arjantin, Brezilya, Kore, } \\
\text { Malezya, Tayland, Çin, Çek } \\
\text { Cumhuriyeti, Polonya ve } \\
\text { Rusya } \\
\text { Engle-Granger testi ve } \\
\text { Gregory ve Hansen (1996) } \\
\text { yapısal kirılmalı } \\
\text { eşbütünleşme testi } \\
\text { Ocak 1988- Mart 2006 }\end{array}$ & $\begin{array}{l}\text { Engle-Granger yöntemi Türkiye ile } \\
\text { diğer ülke borsaları arasında uzun } \\
\text { dönem ilişki olmadığını } \\
\text { göstermesine rağmen Gregory ve } \\
\text { Hansen (1996) testi, Türkiye ile } \\
\text { Almanya, Fransa, İngiltere, ABD, } \\
\text { Japonya, Kore, Tayland, Çin ve } \\
\text { Brezilya borsaları arasında uzun } \\
\text { dönem ilişkinin olduğuna yönelik } \\
\text { sonuçlar vermiştir. }\end{array}$ \\
\hline İpekten ve Aksu (2009) & $\begin{array}{ll}\text { - } & \text { ABD Dow Jones ve Türkiye } \\
& \text { IMKB } \\
\text { - } & \text { ARDL Sinır Testi } \\
\text { - } & \text { 1992:12-2008:12 }\end{array}$ & $\begin{array}{l}\text { ABD Dow Jones endeksi uzun } \\
\text { dönemde IMKB endeksini pozitif } \\
\text { yönde etkilemektedir. Kisa } \\
\text { dönemde Dow Jones endeksinin } \\
\text { cari değeri İMKB'yi pozitif yönde, } \\
\text { gecikmeli değeri ise negatif yönde } \\
\text { etkilemektedir. }\end{array}$ \\
\hline Korkmaz vd. (2009) & $\begin{array}{ll}\text { - } & 23 \text { gelişmiş ve } 23 \text { gelişmekte } \\
\text { olan ülke ve Türkiye } \\
\text { - } \quad \text { Geleneksel (Johansen) ve } \\
\text { yapısal kırılmayı dikkate } \\
\text { alan (Gregory-Hansen) } \\
\text { eşbütünleşme testleri } \\
\text { - } \quad \text { Ocak } 1995 \text { ile Aralık } 2007 \\
\end{array}$ & $\begin{array}{l}\text { Johansen testine göre Türkiye } 8 \\
\text { gelişmiş ülke, } 3 \text { gelişmekte olan } \\
\text { ülke, Gregory-Hansen testine göre } \\
13 \text { gelişmiş ülke, } 21 \text { gelişmekte } \\
\text { olan ülke hisse senedi piyasası ile } \\
\text { eş-bütünleşiktir. }\end{array}$ \\
\hline Küçükkaya (2009) & $\begin{array}{ll}\text { - } & \text { ABD ve Türkiye hisse } \\
& \text { senedi piyasaları } \\
\text { - } & \text { Johansen ko-entegrasyon ve } \\
& \text { Toda-Yamomato nedensellik } \\
\text { - } & \text { Mayıs 1988-Mayıs 2008 } \\
\end{array}$ & $\begin{array}{l}\text { ABD ve Türkiye hisse senedi } \\
\text { piyasaları arasında uzun dönem } \\
\text { ilişkisi yoktur. }\end{array}$ \\
\hline $\begin{array}{l}\text { Y1lanc1 ve } \quad \text { Öztürk } \\
(2010)\end{array}$ & $\begin{array}{l}\text { - Türkiye ve en önemli diş } \\
\text { ticaret ortağ olan } 5 \text { ülke } \\
\text { (ABD, Almanya, Hollanda, } \\
\text { İspanya ve İngiltere) } \\
\text { Engle-Granger (1987) ve } \\
\text { yapısal kirilmalı Hatemi-J } \\
\text { (2008) } \\
\text { Ocak 1995 ile Aralık } 2009\end{array}$ & $\begin{array}{l}\text { Engle-Granger (1987) test } \\
\text { sonuçları İMKB ile hiçbir ülkenin } \\
\text { hisse senedi piyasası arasında ilişki } \\
\text { olmadığını, iki yapısal kırılmayı } \\
\text { dikkate alan Hatemi-J (2008) testi } \\
\text { ise İMKB } 100 \text { ile Almanya ve } \\
\text { İspanya piyasaları arasında ilişki } \\
\text { olduğunu göstermiştir. }\end{array}$ \\
\hline Vuran (2010) & 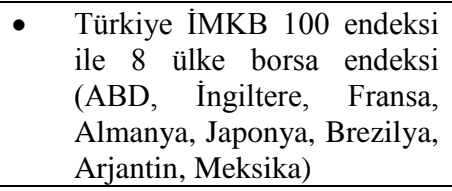 & $\begin{array}{l}\text { IMKB } 100 \text { endeksi İngiltere, } \\
\text { Almanya, Brezilya, Arjantin ve } \\
\text { Meksika borsa endeksleri ile uzun } \\
\text { dönemde ilişkilidir. }\end{array}$ \\
\hline
\end{tabular}




\begin{tabular}{|c|c|c|}
\hline & $\begin{array}{ll}\text { - } & \text { Johansen Eşbütünleşme } \\
& \text { Analizi } \\
\text { - } & \text { Ocak 2006-Ocak 2009 } \\
\end{array}$ & \\
\hline $\begin{array}{l}\text { Bozoklu ve } \text { Saydam } \\
(2010)\end{array}$ & 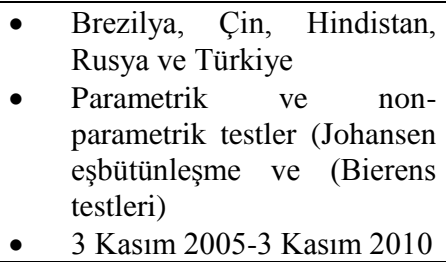 & $\begin{array}{l}\text { Uygulanan parametrik ve non- } \\
\text { parametrik yöntemler sonucunda } \\
\text { incelenen beş sermaye piyasasının } \\
\text { uzun dönemde eş-bütünleşik } \\
\text { oldukları belirlenmiştir. }\end{array}$ \\
\hline Gözbaş1 (2010) & 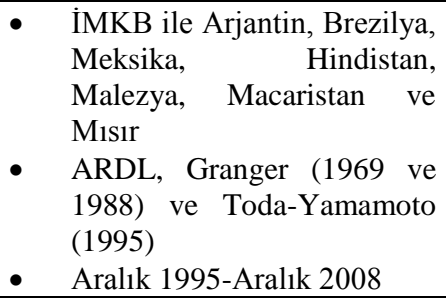 & $\begin{array}{l}\text { Uzun dönemde İMKB ile Brezilya, } \\
\text { Hindistan ve Misır borsaları } \\
\text { arasında, kısa dönemde ise bu üç } \\
\text { ülkenin yanı sıra Meksika ve } \\
\text { Macaristan borsaları arasında ilişki } \\
\text { mevcuttur. }\end{array}$ \\
\hline Berument vd.(2011) & 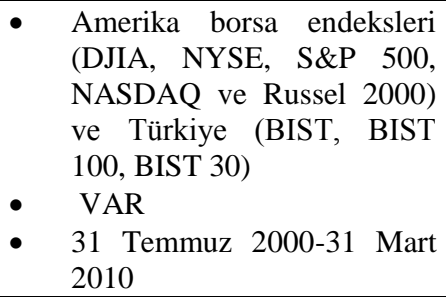 & $\begin{array}{llr}\text { Türkiye } & \text { borsası, } & \text { ABD } \\
\text { borsalarındaki } & \text { gelişmeleri takip } \\
\text { etmektedir ve } & \text { iki borsa arasında } \\
\text { pozitif yönlü } & \text { anlamlı bir ilişki } \\
\text { vardır. } & & \end{array}$ \\
\hline $\begin{array}{l}\text { Boztosun ve Çelik } \\
(2011)\end{array}$ & 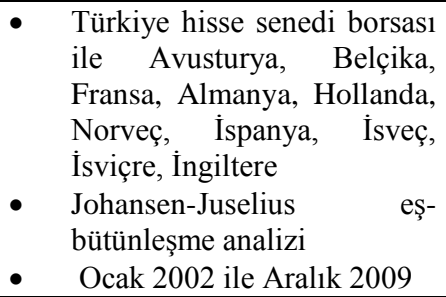 & $\begin{array}{l}\text { Türkiye hisse senedi borsasının } \\
\text { uzun dönemde Norveç, Hollanda, } \\
\text { Belçika, Almanya ve İngiltere } \\
\text { borsası ile eş-bütünleşik olduğu } \\
\text { tespit edilmiştir. }\end{array}$ \\
\hline $\begin{array}{ll}\text { İbicioğlu } & \text { ve } \\
\text { Kapusuzoğlu (2011) }\end{array}$ & $\begin{array}{ll}\text { - } & \text { Türkiye ile Avrupa Birliği } \\
\text { üyesi } 6 \text { Akdeniz ülkesi } \\
\text { (Fransa, İtalya, İspanya, } \\
\text { Yunanistan, Malta ve } \\
\text { Hirvatistan) } \\
\text { - Johansen eş-bütünleşme ve } \\
\text { Granger nedensellik testi } \\
\text { - } 01.07 .2002-01.03 .2010\end{array}$ & $\begin{array}{l}\text { Türkiye İMKB } 100 \text { endeksi ile AB } \\
\text { üyesi } 6 \text { Akdeniz ülkesinin hisse } \\
\text { senedi piyasaları uzun dönemde } \\
\text { birlikte hareket etmektedir. }\end{array}$ \\
\hline $\begin{array}{lll}\text { Bulut } & \text { ve } & \text { Özdemir } \\
(2012) & & \end{array}$ & $\begin{array}{ll}\text { - } & \text { Türkiye İMKB ve ABD } \\
& \text { Dow Jones Industrial } \\
\text { - } & \text { Johansen eşbütünleşme ve } \\
\text { Granger nedensellik analizi } \\
\text { - } \\
\quad 05.01 .2001-30.12 .2010\end{array}$ & $\begin{array}{l}\text { İMKB ve Dow Jones Industrial } \\
\text { serileri arasında uzun dönem } \\
\text { ilişkisi vardır. Kısa dönemde ise } \\
\text { Dow Jones IMKB'yi anlaml } \\
\text { şekilde etkilemektedir. }\end{array}$ \\
\hline $\begin{array}{l}\text { Evlimoğlu ve Çondur } \\
(2012)\end{array}$ & $\begin{array}{l}\text { - Türkiye, Brezilya, Çin, } \\
\text { Hindistan, Rusya, Japonya, } \\
\text { Almanya ve Amerika S\&P } \\
500 \text { endeksi }\end{array}$ & $\begin{array}{l}\text { İMKB ile Amerikan borsas } \\
\text { arasındaki ilişki kriz öncesinde } \\
\text { düşük olmasına karşın, kriz }\end{array}$ \\
\hline
\end{tabular}




\begin{tabular}{|c|c|c|}
\hline & $\begin{array}{l}\text { - } \quad \text { VAR modeli, Etki-Tepki ve } \\
\text { Varyans Ayrıştırma } \\
\text { - } \begin{array}{l}\text { 05.01.2004-31.07.2007 ve } \\
\text { 01.08.2007-01.01.2010 } \\
\text { olmak üzere iki dönem }\end{array} \\
\end{array}$ & sonrasında oldukça yüksektir. \\
\hline Benli vd. (2012) & 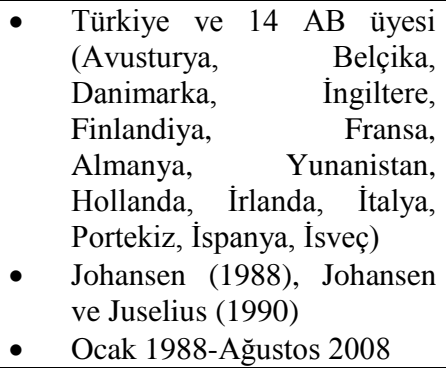 & $\begin{array}{l}\text { Türkiye ve } 14 \text { AB üyesi hisse } \\
\text { senedi piyasaları arasında uzun } \\
\text { dönem eş-bütünleşme ilişkisi } \\
\text { olduğu sonucuna ulaşılmıştır. }\end{array}$ \\
\hline $\begin{array}{l}\text { Samırkaş ve Düzakın } \\
(2013)\end{array}$ & 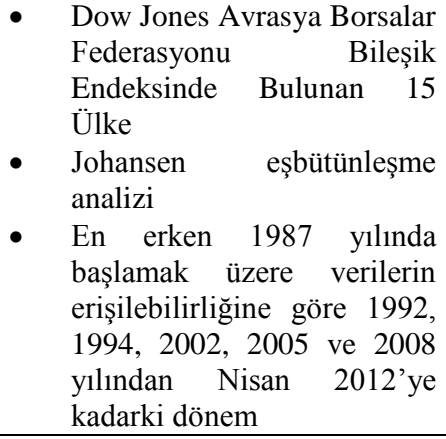 & $\begin{array}{l}\text { Türkiye ile BAE, Bahreyn, } \\
\text { Bulgaristan, Hırvatistan, } \\
\text { Kazakistan, Pakistan, Romanya ve } \\
\text { Ürdün arasında anlamlı bir ilişki } \\
\text { yokken sadece Misır ile uzun } \\
\text { dönemli ortak hareket etme eğilimi } \\
\text { tespit edilmiştir. }\end{array}$ \\
\hline Keskin Benli (2014) & $\begin{array}{l}\text { - Latin Amerika'da Brezilya, } \\
\text { Şili, Kolombiya, Meksika, } \\
\text { Peru; Avrupa Orta Doğu ve } \\
\text { Afrika'da Çek Cumhuriyeti, } \\
\text { Misır, Polonya, Yunanistan, } \\
\text { Macaristan, Rusya, Güney } \\
\text { Afrika; Asya'da Çin, } \\
\text { Hindistan, Endonezya, Kore, } \\
\text { Malezya, Filipinler, Tayvan } \\
\text { ve Tayland } \\
\text { Johansen eşbütünleşme testi } \\
30 \text { Aralı 1994-30 Eylül } \\
2013\end{array}$ & $\begin{array}{l}\text { Uzun dönemde Türkiye ile } \\
\text { Kolombiya ve Meksika borsaları } \\
\text { arasında anlamlı bir ilişki olmakla } \\
\text { birlikte Türkiye ile diğer } \\
\text { gelişmekte olan ülkelerin hisse } \\
\text { senedi piyasaları arasında anlamlı } \\
\text { bir ilişki bulunamamıştır. }\end{array}$ \\
\hline Yildız ve Aksoy (2014) & 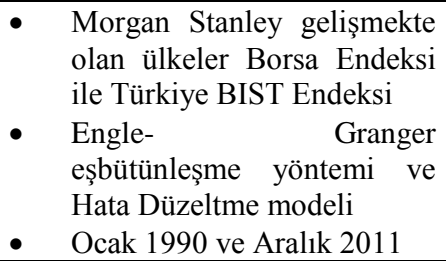 & $\begin{array}{l}\text { Eşbütünleşme analizine göre borsa } \\
\text { endeksleri uzun dönemde birlikte } \\
\text { hareket etmektedirler. }\end{array}$ \\
\hline Akel (2015) & $\begin{array}{ll}\text { - } & \text { Brezilya, Endonezya, Güney } \\
& \text { Afrika, Hindistan ve Türkiye } \\
\text { - } & \text { Johansen eşbütünleşme } \\
\text { analizi ile Granger } \\
\text { nedensellik testi } \\
\text { - } \quad \text { Kasim 2000- Aralık } 2013\end{array}$ & $\begin{array}{l}\text { Kırılgan beşli olarak adlandırılan } \\
\text { bu ülkelerin sermaye piyasaları } \\
\text { arasında kısa ve uzun dönem eş- } \\
\text { bütünleşme ve nedensellik ilişkisi } \\
\text { mevcuttur. }\end{array}$ \\
\hline
\end{tabular}




\section{VERİ SETİ}

$\mathrm{Bu}$ çalışmada yükselen piyasa ekonomileri arasında yer alan Türkiye ve BRICS (Brezilya, Rusya, Hindistan, Çin ve Güney Afrika) ülkeleri sermaye piyasalarında benzer eğilimlerinin varlığı araştırılmaktadır. Bu doğrultuda 2000.12016.12 döneminde Türkiye ve BRICS ülkelerinin her birine ait aylık menkul kıymetler borsa endeksleri arasında eş-bütünleşme ilişkisinin olup olmadığ zaman serisi analiz yöntemleri ile test edilecektir.

Çalışmada kullanılan borsa endeksleri, Morgan Stanley Capital International (MSCI) resmi internet sitesinden derlenmiştir. MSCI'dan alınan borsa endeksleri, hisse senetlerinin $\mathrm{ABD}$ doları cinsinden günlük kapanış değerlerini yansıtmaktadır. Ampirik analiz öncesinde derlenen günlük ham veriler aylık serilere dönüştürülmüş ve ardından doğal logaritmaları alınarak Eviews 8.0 yazılımları ile uygulamada kullanılmıştır. İstanbul Menkul Kıymetler Borsası'nın BRICS ülkelerinden her birine ait borsa endeksiyle uzun dönemde koentegre olup olmadığını araştırmak amacıyla tahmin edilecek denklem Eşitlik 1'de gösterilmektedir.

$$
T R_{t}=\alpha_{0}+\alpha_{1} \text { BRICS }_{t}+\varepsilon_{t}
$$

Eşitlikte $T R_{t}$ Türkiye BIST 100 borsa endeks değerini, BRICS BRICS ülkelerinden her birine ait borsa endeksini, $\varepsilon_{i, t}$ ise hata terimini ifade etmektedir. Tablo 2, çalışmada incelenen ülkelerin menkul kıymetler borsalarına ilişkin bilgiler sunmaktadir.

Tablo 2. Çalışmada İncelenen Ülkeler ve Hisse Senedi Piyasaları

\begin{tabular}{lll}
\hline Ülke & Borsa İsmi & Endeks Türü \\
\hline Türkiye & Borsa İstanbul 100 Endeksi & İMKB 100 \\
Brezilya & Bolsa de Valores de Sao Paulo (BOVESPA) & IBOVESPA \\
Rusya & Moscow Times Index & RTSI Index \\
Hindistan & Bombay Stock Exchange & BSE Sensex \\
Çin & Hong Kong Stock Exchange & HSI Index \\
Güney Afrika & Johannesburg Stock Exchange & JSE \\
\hline
\end{tabular}

Türkiye ve BRICS ülkeleri aylık borsa endekslerinin logaritmik değerlerine ilişkin tanımlayıcı istatistikler Tablo 3 'te verilmiştir. Borsa endeksleri birbiri ile mukayese edildiğinde en yüksek işlem hacmine sahip borsanın Çin Hong Kong borsas1 olduğu görülmektedir. İşlem hacmi büyüklüğüne göre Çin borsasını Brezilya, Rusya, Türkiye ve Güney Afrika takip etmektedir. En düşük işlem hacmine sahip borsa ise Hindistan Bombay borsasıdır. Ayrıca en yüksek negatif çarpıklığın Türkiye'de, en düşük ise Çin'de olduğu gözlenmiştir. Borsa endekslerine ait Jarque-Bera istatistikleri ise serilerin normal dağıldığını ifade eden boş hipotezin \%99 önem düzeyinde reddedildiğini ve hiçbir borsa endeksinin normal dağılıma sahip olmadığını ortaya koymaktadır. Tanımlayıcı istatistiklerde basıklık değerinin 3 , çarpıklık değerinin ise 0 olması serinin normal 
dağılıma sahip olduğunun bir diğer göstergesidir. Tablo 3 'ten her bir ülkenin borsa endeksine ait çarpıklık ve basıklık değerleri incelendiğinde normal bir dağılım göstermediği bulgusu teyit edilmektedir. Çarpıklık değerinin negatif işaret alması, serilerin sola çarpık bir yapıda olduğunu, basıklık istatistikleri incelendiğinde ise dik bir şekle sahip olduğu görülmüştür.

Tablo 3. Türkiye ve BRICS Ülkelerinin Borsa Endekslerine İlişkin Tanımlayıcı İstatistikler

\begin{tabular}{lcccccc}
\hline Değişken & Türkiye & Brezilya & Rusya & Hindistan & Çin & Güney Afrika \\
\hline Mean & 5.88 & 7.34 & 6.34 & 5.60 & 8.78 & 5.81 \\
Median & 6.08 & 7.51 & 6.44 & 5.92 & 8.85 & 6.06 \\
Maximum & 6.67 & 8.44 & 7.38 & 6.50 & 9.32 & 6.43 \\
Minimum & 4.48 & 5.64 & 5.01 & 4.34 & 8.06 & 4.82 \\
Std.Sapma & 0.54 & 0.70 & 0.57 & 0.63 & 0.32 & 0.50 \\
Skewness & -1.00 & -0.45 & -0.42 & -0.62 & -0.38 & -0.66 \\
Kurtosis & 2.93 & 2.01 & 2.31 & 1.90 & 2.07 & 1.90 \\
Jarque-Bera & $32.9^{*}$ & $14.8^{*}$ & $9.63^{*}$ & $22.8^{*}$ & $11.79^{*}$ & $24.1^{*}$ \\
\hline
\end{tabular}

Türkiye ve BRICS ülkelerinin borsa endeksleri arasındaki korelasyon ilişkisini tespit etmek amacıyla korelasyon matrisi oluşturulmuş ve ulaşılan sonuçlar Tablo 4'te sunulmuştur. Tabloda yer alan verilerden hareketle yükselen piyasa ekonomileri olarak değerlendirilen bu altı ülkede benzer düşüş ve yükselişlerin gözlendiği ve bu doğrultuda güçlü bir korelasyon ilişkisi olduğu tespit edilmiştir. Korelasyon matrisine göre altı ülke içinde en zayıf korelasyon Rusya ve Çin borsaları arasında iken, en güçlü korelasyon Hindistan ve Güney Afrika borsaları arasındadır. Türkiye BIST endeksine ilişkin sonuçlara göre en güçlü korelasyon ilişkisinin olduğu ülke borsası Hindistan iken, en zayıf korelasyonun Rusya borsası ile olduğu belirlenmiş̧tir. Tablo 4'te yer alan sonuçlara göre yapılabilecek bir diğer önemli çıkarım ise uzak doğu asya ülkelerinden Çin ve Hindistan borsaları arasındaki güçlü ilişkidir.

Tablo 4. Türkiye ve BRICS Ülkeleri Borsa Endekslerinin Korelasyon Matrisi

\begin{tabular}{lcccccc}
\hline & Türkiye & Brezilya & Rusya & Hindistan & Çin & Güney Afrika \\
\hline Türkiye & 1 & & & & & \\
Brezilya & 0.889 & 1 & & & & \\
Rusya & 0.747 & 0.846 & 1 & & & \\
Hindistan & 0.898 & 0.912 & 0.800 & 1 & & \\
Çin & 0.873 & 0.784 & 0.615 & 0.918 & 1 & \\
Güney Afrika & 0.877 & 0.904 & 0.827 & 0.971 & 0.896 & 1 \\
\hline
\end{tabular}

\section{EKONOMETRÍK YÖNTEM VE AMPİIIK BULGULAR}

Seriler arasında eş-bütünleşme ilişkisinin varlığı araştırılmadan önce serilerin durağanlık mertebelerinin belirlenmesi amacıyla durağanlık testleri yapılmalıdır. Ancak serilerde ortaya çıkacak yapısal kırılmalar birim kök test sonuçları üzerinde farklı etkiler yaratabilecektir (Carrioni-Silvestre vd., 2009: 1755). Serilerde birim kökün varlığını araştırmak üzere geliştirilen Genişletilmiş 
Dickey-Fuller-ADF (Dickey ve Fuller, 1989), Phillips-Perron-PP (Phillips ve Perron, 1988), KPSS (Kwiatkowski vd., 1992) gibi geleneksel birim kök testleri, ekonomik veya siyasi gelişmeler neticesinde ortaya çıkabilecek yapısal kırılmaları dikkate almamalarından dolayı eleştirilmektedir. Perron (1989), yapısal kırılmaların göz ardı edildiği durumlarda standart birim kök testlerinin durağanlığa ilişkin yanıltıcı sonuçlar vereceğine yönelik uyarıda bulunmaktadır (Perron, 1989: 1362). Yapısal kırılmaların birim kök test sonuçları üzerindeki etkisini kontrol etmek amacıyla geliştirilen testler, kırılma döneminin içsel veya dışsal belirlenmesine göre sınıflandırılabilir. Perron (1989) kırılmanın dışsal olarak belirlendiğini kabul etmesine rağmen Zivot ve Andrews (1992), Perron(1989)'un kullandığı serilerle aynı analizi yapmış ancak kırılmanın içsel belirlendiğini varsaymasından dolayı farklı sonuçlara ulaşmıştır (Zivot ve Andrews, 1992: 251-254).

$\mathrm{Bu}$ yöntemlerin yanı sıra Lee ve Strazicich (2003), serilerde iki yapısal kırılmayı dikkate alan Minimum LM birim kök testini, Carrion-i Silvestre vd. (2009) ise kırılma sayısının beşe kadar olabileceği farklı bir yöntem daha geliştirmiştir. Bu çalışmada borsa endekslerinin durağanlık analizi Carrion-iSilvestre vd. (2009) tarafindan geliştirilen çoklu yapısal kırılmalı birim kök testi ile araştırılmış ve ardından borsa endeksleri arasında uzun dönemli eş-bütünleşme ilişkisi, yapısal kırılmalı Maki (2012) yöntemi ile tespit edilmiştir. Değişkenlerin uzun dönem katsayılarına ise FMOLS ve DOLS tahmincileri ile erişilmiştir.

Carrion-i Silvestre vd. (2009) birim kök testinde kırılma tarihleri belirlenirken Bai ve Perron(2003) yöntemi takip edilerek dinamik programlama yaklaşımı kullanılmıştır. Bu yöntem boş hipotezde yapısal kırılmanın varlığında serinin birim kök içerdiğini, alternatif hipotez ise serinin durağan olduğunu belirtmektedir. Serilerin yapısal kırılmanın varlığında birim kök içerip içermediğini belirlemek üzere 5 farklı istatistik hesaplanmaktadır. $\mathrm{Bu}$ istatistiklerden ilki, Elliott vd. (1996) ve Perron ve Rodriguez (2003) yöntemleri takip edilerek oluşturulan $P_{T}^{G L S}$ (the feasible point optimal statistics)'tir (Carrion-i Silvestre vd., 2009: 1760).

$$
P_{T}^{G L S}\left(\lambda^{0}\right)=\left\{S\left(\bar{\alpha}, \lambda^{0}\right)-\bar{\alpha} S\left(1, \lambda^{0}\right)\right\} / s^{2}\left(\lambda^{0}\right)
$$

$\mathrm{Bu}$ istatistiğin yanısıra Perron ve Rodriguez (2003)'i takiben çoklu yapısal kırılmaya izin veren $\mathrm{Ng}$ ve Perron(2001) M-class of test analizi kullanılmış 3 istatistik daha geliştirilmiştir (Carrion-i Silvestre vd., 2009: 1762).

$$
\begin{aligned}
& M Z_{\alpha}^{G L S}\left(\lambda^{0}\right)=\left(T^{-1} \tilde{y}_{T}^{2}-s\left(\lambda^{0}\right)^{2}\right)\left(2 T^{-2} \sum_{t=1}^{T} \tilde{y}_{t-1}^{2}\right)^{-1} \\
& M S B^{G L S}\left(\lambda^{0}\right)=\left(s\left(\lambda^{0}\right)^{-2} T^{-2} \sum_{t=1}^{T} \tilde{y}_{t-1}^{2}\right)^{\frac{1}{2}} \\
& M Z_{t}^{G L S}\left(\lambda^{0}\right)=\left(T^{-1} \tilde{y}_{T}^{2}-s\left(\lambda^{0}\right)^{2}\right)\left(4 s\left(\lambda^{0}\right)^{2} T^{-2} \sum_{t=1}^{T} \tilde{y}_{t-1}^{2}\right)^{-\frac{1}{2}}
\end{aligned}
$$


$\mathrm{Ng}$ ve Perron(2001) çalışması takip edilerek türetilen $M P_{T}^{G L S}$ (modified feasible point optimal) test istatistiği ise Eşitlik 6'da gösterilmiştir.

$$
M P_{T}^{G L S}\left(\lambda^{0}\right)=\left[\bar{c}^{2} T^{-2} \sum_{t=1}^{T} \tilde{y}_{t-1}^{2}+(1-\bar{c}) T^{-1} \tilde{y}_{T}^{2}\right] / s\left(\lambda^{0}\right)^{2}
$$

$\mathrm{Bu}$ yöntem sonucunda serilerin durağan olduğuna karar verilebilmesi için elde edilen test istatistiklerinin Carrioni-Silvestre vd. (2009) kritik değerinden küçük olması gerekmektedir. Bu doğrultuda yapısal kırılmanın varlığında serinin birim kök içerdiğini ifade eden boş hipotez reddedilecek ve alternatif hipotez kabul edilecektir. Bu çalışmada kullanılan değişkenlerin seviye değerlerine ve birinci farklarına uygulanan 5 kırılmalı birim kök test sonuçları Tablo 5'te gösterilmiştir.

Tablo 5. Carrioni-Silvestre vd. (2009) Çoklu Yapısal Kırılmalı Birim Kök Testi Sonuçları

\begin{tabular}{|c|c|c|c|c|c|c|}
\hline Değişken & $P_{T}$ & $M P_{T}$ & $M Z_{\alpha}$ & $M S B$ & $M Z_{T}$ & Kırılma Tarihleri \\
\hline TURKEY & $10.3(8.65)$ & $10.0(8.65)$ & $-40.2(-46.0)$ & $0.11(0.10)$ & $-4.48(-4.79)$ & $\begin{array}{l}2001.8-2003.7- \\
2006.2-2007.12- \\
2013.4\end{array}$ \\
\hline$\triangle T U R K E Y$ & $1.00(5.54)$ & $1.00(5.54)$ & $-97.4(17.3)$ & $0.07(0.16)$ & $-6.96(-2.89)$ & - \\
\hline$B R A Z I L$ & $17.1(9.13)$ & $15.9(9.13)$ & $-27.2(-46.5)$ & $0.13(0.10)$ & $-3.68(-4.82)$ & $\begin{array}{l}2002.9-2004.6- \\
2008.5-2012.2- \\
2014.8\end{array}$ \\
\hline$\triangle B R A Z I L$ & $0.99(5.54)$ & $1.00(5.54)$ & $-96.8(-17.3)$ & $0.07(0.16)$ & $-6.94(-2.89)$ & - \\
\hline RUSSIA & $24.8(8.95)$ & $21.9(8.95)$ & $-19.4(-47.1)$ & $0.16(0.10)$ & $-3.11(-4.84)$ & $\begin{array}{l}2001.8-2004.3- \\
2006.4-2009.2- \\
2011.4\end{array}$ \\
\hline$\triangle R U S S I A$ & $0.99(5.54)$ & $1.00(5.54)$ & $-96.8(-17.3)$ & $0.07(0.16)$ & $-6.94(-2.89)$ & - \\
\hline INDIA & $20.9(9.28)$ & $19.0(9.28)$ & $-23.4(-47.5)$ & $0.14(0.10)$ & $-3.42(-4.85)$ & $\begin{array}{l}2001.8-2005.4- \\
2007.5-2009.2- \\
2011.12\end{array}$ \\
\hline$\triangle I N D I A$ & $1.29(5.54)$ & $1.18(5.54)$ & $-78.5(-17.3)$ & $0.07(0.16)$ & $-6.25(-2.89)$ & - \\
\hline CHINA & $20.2(9.26)$ & $18.6(9.26)$ & $-23.7(-47.1)$ & $0.14(0.10)$ & $-3.43(-4.82)$ & $\begin{array}{l}2001.9-2004.2- \\
2005.10-2007.10- \\
2011.5\end{array}$ \\
\hline$\triangle C H I N A$ & $1.63(5.54)$ & $1.45(5.54)$ & $-64.8(-17.3)$ & $0.08(0.16)$ & $-5.68(-2.89)$ & - \\
\hline S. AFRICA & $15.4(9.20)$ & $14.5(9.20)$ & $-30.7(-47.4)$ & $0.12(0.10)$ & $-3.89(-4.84)$ & $\begin{array}{l}2001.8-2004.3- \\
2006.4-2008.5- \\
2011.4\end{array}$ \\
\hline$\triangle S . A F R I C_{1}$ & $1.03(5.54)$ & $1.03(5.54)$ & $-97.0(-17.3)$ & $0.07(0.16)$ & $-6.94(-2.89)$ & - \\
\hline
\end{tabular}

Not: $\Delta$ serilerin birinci farkının alındığı göstermektedir. Parantez içindeki değerler \%95 önem düzeyinde seriye ait kritik değerlerdir.

Tablo 5'te ülkelere ait borsa endekslerinin seviye değerlerine ait birim kök testi sonuçları incelendiğinde Carrioni-Silvestre vd. (2009) tarafindan geliştirilen yöntemle hesaplanmış 5 test istatistiğinin hem Türkiye hem de BRICS ülkelerinde kritik değerden daha büyük olduğu tespit edilmiştir. Bu bulgu, yapısal kırılmanın 
varlığında tüm ülkelere ait borsa endekslerinin birim kök içerdiğini belirten boş hipotezin kabul edileceği anlamına gelmektedir. Serilerin orijinal değerlerinde birim kök içerdiği belirlendiği için birinci farkları alınarak yeniden CarrioniSilvestre vd. (2009) durağanlık testine tabi tutulmuştur. Tabloda yer alan bulgular değerlendirildiğinde tüm serilerin birinci farkına ilişkin hesaplanan istatistikler kritik değerden küçük olduğu için boş hipotezin reddedileceği ve serilerin durağanlaştığı görülmüsstür. Bu doğrultuda çalışma kapsamında incelenen Türkiye ve BRICS ülkeleri borsa endekslerine ait serilerin birinci derecede bütünleşik oldukları tespit edilmiştir.

Kırılma tarihleri incelendiğinde Türkiye ve BRICS ülkelerinin 2008 küresel finans krizinden etkilendiği açıkça gözlenmektedir. Özellikle Türkiye için 2001 ekonomik krizi ve 3 Kasım 2002 tarihinde yapılan genel seçim sonrasında Adalet ve Kalkınma Partisinin tek başına iktidara gelişinin borsa endeksinde önemli hareketlenmelere yol açtığı önerilen kırılma tarihleri üzerinden açıkça görülmektedir. Ayrıca Türkiye için bir diğer önemli kırılma tarihi ise 2013 yılı nisan ayıdır. 16 Mayıs 2013 tarihinde uluslararası kredi derecelendirme kuruluşlarından Moody's'in Türkiye'nin kredi notunu yatırım yapılabilir seviyeye yükseltmesi, Mayıs ayı içerisinde BIST 100 endeksinin tarihi zirveye yükselmesine yol açmıştır. Bu sonuçlara göre Carrioni-Silvestre vd. (2009) çoklu yapısal kırılmalı birim kök testinin Türkiye için önemli kırılma tarihlerini doğru bir şekilde tespit ettiği görülmüştür.

Serilerin bütünleşme dereceleri belirlendikten sonra uzun dönem ilişkinin olup olmadığı eş-bütünleşme yöntemleri ile araştırılmalıdır. Türkiye ve BRICS ülkelerinin borsa endeksleri arasında uzun dönemde benzer hareketlerin olup olmadığı çoklu yapısal kırılmaya izin veren Maki (2012) eş-bütünleşme yöntemi ile test edilmiştir.

Yapısal kırılmayı dikkate alarak değişkenler arasında uzun dönem ilişkinin varlığını araştıran Gregory ve Hansen (1996) bir kırılma tarihi, Hatemi-J(2008) ise iki kırılma tarihi belirlemektedir. Maki (2012), kırılma sayısının üçten daha fazla olduğu durumlarda kullanılmak üzere eş-bütünleşme ilişkisini araştırmak üzere diğer yöntemlerden daha güçlü tahminlerde bulunan bir yöntem geliştirmiştir. Çoklu kırılmanın varlığında eş-bütünleşme ilişkisini araştırmak üzere dört model tahmin edilmektedir. Eşitlik 7'de gösterilen ilk model seviyede kırılmayı, Eşitlik 8 seviye ve trendde kırılmayı; Eşitlik 9 rejim kırılmasını, Eşitlik 10 ise trend ve rejim kırılmasını gösteren modellerdir (Maki, 2012: 2011-2012).

$\mathrm{y}_{t}=\mu+\sum_{i=1}^{k} \mu_{i} D_{i, t}+\beta^{\prime} x_{t}+u_{t}$
$\mathrm{y}_{t}=\mu+\sum_{i=1}^{k} \mu_{i} D_{i, t}+\beta^{\prime} x_{t}+\sum_{i=1}^{k} \beta_{i}^{\prime} x_{t} D_{i, t}+u_{t}$
$\mathrm{y}_{t}=\mu+\sum_{i=1}^{k} \mu_{i} D_{i, t}+\gamma t+\beta^{\prime} x_{t}+\sum_{i=1}^{k} \beta_{i}^{\prime} x_{t} D_{i, t}+u_{t}$ 


$$
\mathrm{y}_{t}=\mu+\sum_{i=1}^{k} \mu_{i} D_{i, t}+\gamma t+\sum_{i=1}^{k} \gamma_{i} t D_{i, t}+\beta^{\prime} x_{t}+\sum_{i=1}^{k} \beta_{i}^{\prime} x_{t} D_{i, t}
$$

Maki (2012), kırılma sayısına (birden beșe kadar olmak üzere), bağımsız değişken sayısına ve kullanılan modele göre farklılaşan \%99, 95 ve 90 önem düzeylerine ait kritik değerleri kendi çalışmasında paylaşmaktadır. Bu yöntem boş hipotezde yapısal kırılmanın varlığında eş-bütünleşme ilişkisi olmadığını; alternatif hipotezde ise eş-bütünleşmenin varlığını test etmektedir (Maki, 2012: 2012-2013). Elde edilen test istatistiğinin Maki (2012) kritik tablo değerinden küçük olması boş hipotezin reddedileceği ve seriler arasında uzun dönem ilişki olduğu anlamına gelecektir. Bu çalışmada Türkiye ve BRICS ülkeleri borsa endekslerinin uzun dönem ilişkisini tespit etmek amacıyla yapılan Maki (2012) çoklu yapısal kırılmalı eş-bütünleşme analiz sonuçları Tablo 6' da sunulmuştur.

\begin{tabular}{|c|c|c|c|c|c|}
\hline & $\begin{array}{l}\text { Türkiye- } \\
\text { Brezilya }\end{array}$ & Türkiye-Rusya & $\begin{array}{c}\text { Türkiye- } \\
\text { Hindistan }\end{array}$ & Türkiye-Çin & $\begin{array}{l}\text { Türkiye- } \\
\text { G.Afrika }\end{array}$ \\
\hline $\begin{array}{l}\text { Model } \\
0\end{array}$ & -5.15 & $-5.61 * *$ & -5.47 & -5.38 & $-5.47 * *$ \\
\hline Kirılma & $\begin{array}{c}2000.12- \\
2002.10- \\
2012.5- \\
2007.12- \\
2003.9 \\
\end{array}$ & $\begin{array}{c}2008.6- \\
2000.11- \\
2003.11- \\
2002.11- \\
2011.8 \\
\end{array}$ & $\begin{array}{c}2000.12- \\
2013.11- \\
2003.3-2012.5- \\
2007.12\end{array}$ & $\begin{array}{l}2001.1- \\
2003.3- \\
2015.1- \\
2008.9- \\
2005.10\end{array}$ & $\begin{array}{c}2000.12- \\
2010.10- \\
2015.1- \\
2003.11- \\
2002.4\end{array}$ \\
\hline Model & -5.34 & $-6.21 * * *$ & -4.03 & $-6.88 * * *$ & $-6.06 * *$ \\
\hline Kırılma & $\begin{array}{c}2007.12- \\
2000.12- \\
2006.4- \\
2008.12- \\
2010.11 \\
\end{array}$ & $\begin{array}{c}2000.12- \\
2003.11- \\
2002.9- \\
2015.1-2006.4\end{array}$ & $\begin{array}{c}2001.8-2003.3- \\
2009.11- \\
2013.11- \\
2011.3\end{array}$ & $\begin{array}{c}2000.12- \\
2003.11- \\
2002.4- \\
2004.12- \\
2013.11 \\
\end{array}$ & $\begin{array}{c}2000.12- \\
2003.11- \\
2002.4- \\
2004.12- \\
2013.11 \\
\end{array}$ \\
\hline $\begin{array}{l}\text { Model } \\
2\end{array}$ & -5.92 & -5.11 & -4.41 & $-6.33^{*}$ & -5.94 \\
\hline Kirılma & $\begin{array}{c}2001.11- \\
2014.2-2012.5- \\
2003.3-2006.4\end{array}$ & $\begin{array}{c}2008.6- \\
2000.12- \\
2006.4- \\
2005.4-2010.7\end{array}$ & $\begin{array}{c}2002.1- \\
2013.11- \\
2003.3- \\
2007.12- \\
2009.6\end{array}$ & $\begin{array}{c}2000.11- \\
2010.11- \\
2003.11- \\
2002.3- \\
2013.11\end{array}$ & $\begin{array}{c}2000.11- \\
2010.10- \\
2003.11- \\
2002.3- \\
2013.11\end{array}$ \\
\hline $\begin{array}{l}\text { Model } \\
3\end{array}$ & -6.46 & -5.72 & $-7.68 * *$ & $-7.28 *$ & -6.34 \\
\hline Kirılma & $\begin{array}{c}2002.6-2006.4- \\
2007.12- \\
2003.7-2009.3\end{array}$ & $\begin{array}{c}2003.11- \\
2006.4- \\
2013.11- \\
2002.10- \\
2010.10\end{array}$ & $\begin{array}{l}2003.3-2015.1- \\
2006.4-2012.5- \\
\quad 2007.11\end{array}$ & $\begin{array}{c}2001.1- \\
2003.11- \\
2009.11- \\
2012.9-2006.2\end{array}$ & $\begin{array}{c}2001.1- \\
2003.11- \\
2009.11- \\
2012.9-2006.2\end{array}$ \\
\hline
\end{tabular}

Tablo 6. Maki (2012) Çoklu Yapısal Kırılmalı Eş-bütünleşme Testi Sonuçları

Not: ***, ** ve $*$ sırasıyla $\% 1,5$ ve 10 önem düzeyinde boş hipotezin reddedildiğini gösterir. Maki(2012: 2013) Tablo 1'e göre \%95 önem düzeyine ait kritik değerler Model 0 için -5.42; Model 1 için -5.69; Model 2 için -6.35 ve Model 3 için -7.41 'dir. 
Türkiye ve BRICS ülkeleri borsa endeksleri arasında uzun dönem ilişkinin varlığını test etmek üzere Türkiye BIST endeksi sabit kalmak üzere sırasıyla Brezilya, Rusya, Hindistan, Çin ve Güney Afrika borsa endeksleri kullanılmak üzere 5 farklı uzun dönem denklemi üzerinden Maki (2012) testi uygulanmıştır. Elde edilen sonuçlara göre yapısal kırılmanın varlığında Brezilya ve Türkiye borsalarının uzun dönemde birlikte hareket ettiklerine dair bir bulguya ulaşılamamıştır. Bu doğrultuda BIST ve BOVESPA endeksinin uzun dönemde benzer yönelimler sergilediğini söylemek yanlış olacaktır. Ancak BRICS ülkelerinden Brezilya haricindeki diğer dört ülkeye ilişkin bulgulara baktığımızda Türkiye BIST endeksi ile Rusya RTSI, Hindistan BSE Sensex, Çin Hong Kong ve Güney Afrika JSE borsa endekslerinin uzun dönemde birlikte hareket ettikleri tespit edilmiştir. Maki (2012) test sonuçlarına göre Türkiye-Hindistan borsa endeksleri trend-rejim kırılması dikkate alındığında; Türkiye-Rusya ve TürkiyeGüney Afrika borsaları seviye ve seviye-trend kırılmalarının varlığı dikkate alındığında; Türkiye-Çin borsa endeksleri ise seviye-trend, rejim ve trend-rejim kırılmalarının varlığı dikkate alındığında dahi uzun dönemde eş-bütünleşiktir.

Maki (2012) eş-bütünleşme testi ile uzun dönemde benzer hareketlerin ortaya çıtığı borsa endekslerinin birbirlerini ne yönde ve hangi oranda etkilediğini tespit etmek üzere katsayı tahminleri yapılmalıdır. Bu amaçla her bir değişkenin uzun dönemde aldığı katsayılar Fully-Modified OLS (FMOLS) ve Dinamik EKK (DOLS-Dynamic OLS) yöntemi ile elde edilmiştir. Maki (2012) eş-bütünleşme testi ile Brezilya ve Türkiye borsa endeksleri arasında uzun dönem ilişki tespit edilemediği için Türkiye BIST borsa endeksi bağımlı değişken olmak üzere Rusya, Hindistan, Çin ve Güney Afrika borsa endekslerinin uzun dönem katsayıları tahmin edilmiş ve sonuçlar Tablo 7'de sunulmuştur.

Tablo 7. Katsayı Tahmin Sonuçları

\begin{tabular}{|c|c|c|c|c|c|c|}
\hline & \multicolumn{3}{|c|}{ FMOLS } & \multicolumn{3}{|c|}{ DOLS } \\
\hline & Katsay 1 & $\begin{array}{c}\text { Std. } \\
\text { Sapma }\end{array}$ & $\mathrm{t}$ istatistiği & Katsay 1 & $\begin{array}{c}\text { Std. } \\
\text { Sapma }\end{array}$ & $\mathrm{t}$ istatistiği \\
\hline Rusya & $0.436 * * *$ & 0.094 & 4.595 & $0.438 * * *$ & 0.109 & 4.016 \\
\hline D1 & $-1.035 * * *$ & 0.139 & -7.439 & $-1.012 * * *$ & 0.156 & -6.489 \\
\hline D2 & $0.685 * * *$ & 0.130 & 5.249 & $0.679 * * *$ & 0.145 & 4.678 \\
\hline D3 & $-0.311 * *$ & 0.130 & -2.393 & $-0.285^{* *}$ & 0.144 & -1.980 \\
\hline D4 & 0.037 & 0.110 & 0.337 & 0.038 & 0.122 & 0.314 \\
\hline D5 & $0.323 * * *$ & 0.083 & 3.856 & $0.315 * * *$ & 0.092 & 3.405 \\
\hline$R^{2}$ & 0.840 & & & $R^{2}$ & 0.888 & \\
\hline Hindistan & $1.364 * * *$ & 0.090 & 15.15 & $1.361 * * *$ & 0.110 & 12.30 \\
\hline D1 & $-0.274 * * *$ & 0.082 & -3.332 & $-0.257 * * *$ & 0.097 & -2.628 \\
\hline D2 & $-0.444 * * *$ & 0.090 & -4.890 & $-0.443 * * *$ & 0.101 & -4.367 \\
\hline D3 & $-0.519 * * *$ & 0.114 & -4.555 & $-0525 * * *$ & 0.131 & -3.991 \\
\hline D4 & $0.129 * *$ & 0.067 & 1.922 & $0.129^{*}$ & 0.072 & 1.784 \\
\hline D5 & $-0.159 * *$ & 0.080 & -1.980 & $-0.159 *$ & 0.091 & -1.745 \\
\hline$R^{2}$ & 0.897 & & & $R^{2}$ & 0.915 & \\
\hline Çin & $0.863 * * *$ & 0.107 & 8.039 & $0.857 * * *$ & 0.138 & 6.189 \\
\hline D1 & $-0.630 * * *$ & 0.126 & -4.997 & $-0.590 * * *$ & 0.151 & -3.888 \\
\hline
\end{tabular}




\begin{tabular}{|c|c|c|c|c|c|c|}
\hline D2 & $0.315 * * *$ & 0.090 & 3.509 & $0.314 * * *$ & 0.109 & 2.881 \\
\hline D3 & $-0.261 * * *$ & 0.086 & -3.037 & $-0.265^{* * *}$ & 0.099 & -2.670 \\
\hline D4 & $-0.125 *$ & 0.066 & -1.886 & $-0.131^{*}$ & 0.073 & -1.787 \\
\hline D5 & 0.064 & 0.118 & 0.545 & 0.073 & 0.144 & 0.504 \\
\hline$R^{2}$ & 0.881 & & & $R^{2}$ & 0.901 & \\
\hline Güney & $0.969 * * *$ & 0.088 & 10.92 & $0.970 * * *$ & 0.100 & 9.694 \\
\hline \multicolumn{7}{|l|}{ Afrika } \\
\hline D1 & $-0.861 * * *$ & 0.093 & -9.209 & $-0.869 * * *$ & 0.106 & -8.153 \\
\hline D2 & $0.268 * * *$ & 0.090 & 2.960 & $0.283 * * *$ & 0.103 & 2.735 \\
\hline D3 & $-0.286^{* * *}$ & 0.078 & -3.653 & $-0.275 * * *$ & 0.088 & -3.105 \\
\hline D4 & 0.099 & 0.089 & 1.118 & 0.089 & 0.103 & 0.870 \\
\hline D5 & $-0.196 * * *$ & 0.048 & -4.035 & $-0.202 * * *$ & 0.052 & -3.873 \\
\hline$R^{2}$ & 0.930 & & & $R^{2}$ & 0.945 & \\
\hline
\end{tabular}

Not: ***, ** ve * sırasıyla \%99, 95 ve 90 önem düzeyinde istatistiksel olarak anlamlılı̆̆ ifade etmektedir. DOLS modelinin tahmininde öncül ve gecikme değeri olarak 1 alınmıştır. FMOLS tahmini ise Bartlett Kernel seçeneği ve Newey-West bandwidth metodu ile yapılmıştır.

DOLS ve FMOLS yöntemleri ile uzun dönem katsayı tahmini yapılırken Maki (2012) eş-bütünleşme testinden elde edilen kırılma dönemlerine göre 5 farklı kukla değişken oluşturulmuş ve modellere dahil edilmiştir. Tablo 7'de yer alan bulgular incelendiğinde FMOLS ve DOLS modellerinin benzer sonuçlar verdiği gözlenmiştir. Katsayı tahmin sonuçlarına göre Türkiye ile Rusya, Hindistan, Çin, Güney Afrika borsa endeksleri arasında uzun dönemde pozitif ve \%99 önem düzeyinde istatistiksel olarak anlamlı ilişkilerin mevcut olduğu belirlenmiştir. Bu doğrultuda uzun dönemde bu ülke borsalarının benzer hareketler gösterdiği yorumu yapılabilecektir. Türkiye ve Rusya borsalarının uzun dönem ilişkisini gösteren ilk modelde 2000.12, 2003.11, 2002.9, 2006.4 tarihlerine karşılık gelen kukla değişkenler de istatistiksel açıdan anlamlıdır. Trend kırılması dikkate alınarak Türkiye ile Çin borsa endeksleri arasındaki ilişkinin analiz edildiği modele göre 2000.12, 2003.11, 2002.4, 2004.12 tarihlerine ait kukla değişkenler; Türkiye-Güney Afrika borsa endeksleri arasındaki ilişkinin incelendiği modelde ise 2000.12, 2003.11, 2002.4, 2013.11 tarihlerine ait kukla değişkenler istatistiksel olarak anlamlılığa sahiptir. TürkiyeHindistan borsa endeksleri arasındaki ilişki trend-rejim kırılması dikkate alınarak incelendiğinde ise 2003.3-2015.1-2006.4-2012.5-2007.11 tarihlerinin hepsine ait kukla değişkenlerin istatistiki olarak anlamlı olduğu görülmüştür.

\section{SONUÇ}

1980'li yıllarda sınır ötesi ticari işlemlere yönelik sınırlamaların kaldırılmasını takiben sermayenin uluslararası piyasalara geçişini kolaylaştıran bir dizi politika hayata geçirilmiştir. Finansal liberalizasyon politikaları olarak anılan bu uygulamalar, iç ve diş olmak üzere iki boyutta gerçekleştirilmiştir. İç finansal liberalizasyon ulusal finans sistemine yönelik kısitlama ve kontrollerin hafifletilmesi veya kaldırılmasını içerirken dış finansal liberalizasyonda yerleşiklerin uluslararası finans piyasalarında faaliyette bulunmaları ve dövizle ticaret yapmanın önündeki engellerin kaldırılması söz konusudur. Finansal sisteme yönelik bu gelişmelere bilgi ve iletişim sektörlerinde teknolojik 
yeniliklerin de eşlik etmesi, sermayenin uluslararası ölçekte hareketine imkan tanımış ve bu doğrultuda çok sayıda finansal enstrümanın ortaya çıkmasına ve yatırımcıların risk çeşitlendirmesi yapmasına yol açmıştır. Sıralanan bu gelişmeler neticesinde finansal açıdan daha entegre olan sermaye piyasalarının benzer eğilimler sergilediği gözlenmiştir.

$\mathrm{Bu}$ çalışmada Türkiye ve BRICS ülkeleri sermaye piyasalarının uzun dönemde aynı yönde hareket edip etmediği bir diğer ifadeyle borsa endeksleri arasındaki eş-bütünleşme ilişkisi araştırılmaktadır. Bu amaçla Morgan Stanley Capital International (MSCI) emerging markets borsa endekslerinin Ocak 2000Aralık 2016 dönemi ABD doları cinsinden günlük kapanış değerleri kullanılarak ekonometrik analiz yapılmıştır. Bu çalışma, Türkiye ve BRICS ülkeleri borsa endekslerinin uzun dönemde birlikte hareket eğilimini çoklu yapısal kırılmaların varlığı altında test etmesi yönüyle önceki çalışmalardan farklılaşmakta ve ilgili literatüre katkı sağlamaktadır. Yapısal kırılmalı eş-bütünleşme testi sonuçları Türkiye BIST endeksinin BRICS ülkelerinden Brezilya haricindeki diğer dört ülkenin menkul kıymetler borsası ile uzun dönemde birlikte hareket ettiğini göstermiştir. FMOLS ve DOLS modellerinin uzun dönem katsayı tahmin sonuçları ise Türkiye ile Rusya, Hindistan, Çin, Güney Afrika borsa endeksleri arasında uzun dönemde pozitif ve \%99 önem düzeyinde istatistiksel olarak anlamlı ilişkilerin mevcut olduğunu ortaya koymaktadır. Bu sonuca dayanarak uzun dönemde bu ülke borsalarının benzer eğilimler sergilemesinden ötürü piyasalar arasında risk çeşitlendirmesi yapmanın mümkün olmadığı yorumu yapılabilecektir.

\section{KAYNAKÇA}

Akel, V. (2015). "Kırılgan Beşli Ülkelerinin Hisse Senedi Piyasaları Arasındaki Eşbütünleşme Analizi”. Uluslararası Yönetim İktisat ve İşletme Dergisi, 11(24), 75-96.

Bai, J. ve P. Perron (2003). "Computation and Analysis of Multiple Structural Change Models". Journal of Applied Econometrics, 18, 1-22.

Bayri, O. ve Güloğlu, B. (2005). "Hisse Senedi ve Yabancı Para Piyasalarının Entegrasyonu: Türkiye, AB, ABD Örneği”. İktisat, İsletme ve Finans, 20(234), 13-34.

Benli, Y.K., Başç, S. ve Değirmen, S. (2012). "Common Stochastic Trend and Co-integration in the Stock Exchange Markets: European Countries and Turkey". African Journal of Business Management, 6 (7), 2565-2577.

Berument, H. ve İnce, O. (2005). "Effect of S\&P500'S Return on Emerging Markets: Turkish Experience". Applied Financial Economics Letters, 1, 59-64.

Berument, H. Denaux, Z. ve Yalçın, Y. (2011). "The Effects of US Stock Market on the Istanbul Stock Exchange and its Components". Journal of International Finance and Economics, 11(2), 85-94.

Bozoklu, Ş. ve Saydam, İ.M. (2010). "BRIC Ülkeleri ve Türkiye Arasındaki Sermaye Piyasaları Entegrasyonunun Parametrik ve Parametrik Olmayan Eşbütünleşme Testleri ile Analizi”. Maliye Dergisi, 159, 416-431.

Boztosun, D. ve Çelik, T. (2011). "Türkiye Borsasının Avrupa Borsaları İle Eşbütünleşme Analizi”. Süleyman Demirel Üniversitesi İ̈BF Dergisi, 16(1), 147-162.

Bulut, Ş. ve Özdemir, A. (2012). "İstanbul Menkul Kiymetler Borsası ve "Dow Jones Industrial" Arasındaki İlişki: Eşbütünleşme Analizi”. Yönetim ve Ekonomi, 19(1), 211-224. 
Carrion-i-Silvestre, J. L. (2009). "GLS-Based Unit Root Tests With Multiple Structural Breaks Under Both The Null And The Alternative Hypotheses". Econometric Theory, 25, 17541792.

Çıtak, L. ve Gözbaşı, O. (2007). “IMMKB İle Bazı Önde Gelen Gelişmiş ve Gelişmekte Olan Ülke Borsaları Arasındaki Bütünleşmenin Temel Endeks ve Ana Sektör Endeksleri Temelinde Analizi”. Dokuz Eylül Üniversitesi İktisadi ve İdari Bilimler Fakültesi Dergisi, 22(2), 249271.

Dickey, D.A. ve W.A. Fuller (1979). "Distribution of the Estimators for Autoregressive Time Series with a Unit Root". Journal of the American Statistical Association, 74, 427-431.

Doğan, N. ve Yalçın, Y. (2008). "Yurt Dıı̧ı Borsaların Türkiye Borsasına Sektörel Bazda Etkisi: Asimetrik Eşbütünleşme ve Hata Düzeltme Modeli”. Finans Politik \& Ekonomik Yorumlar, 45(525), 23-34.

Driessen, J. ve Laeven, L. (2003). "The Value of international Portfolio Diversification". (Editör: James A. Hanson, Patrick Honohan ve Giovanni Majnoni). Globalization and National Financial Systems. World Bank ve Oxford University Press, 175-188.

Elliott, G., Rothenberg, T.J. ve Stock, J.H. (1996). "Efficient Tests for an Autoregressive Unit Root". Econometrica, 64, 813-836.

Evlimoğlu, U. ve Çondur, F. (2012). “IMKB ile Bazı Gelişmiş ve Gelişmekte Olan Ülke Borsaları Arasındaki Karşılıklı Bağlantıların Küresel Kriz Öncesi ve Sonrası Dönem İçin İncelenmesi”. Uludağ Üniversitesi İktisadi ve İdari Bilimler Fakültesi Dergisi, 31(1), 3158 .

Eichengreen, B. ve Mussa, M. (1998). "Capital Account Liberalization and the IMF”. Finance and Development, 35(4), 16-19.

Gregory, A.W. ve Hansen, B.E. (1996). "Residual-based Tests for Cointegration in Models with Regime Shifts". Journal of Econometrics, 70, 99-126.

Gündüz, L. ve Omran, M. (2001). "Gelişmekte Olan Piyasalarda Stokastik Trendler ve Hisse Senetleri Fiyatları: Orta Doğu ve Kuzey Afrika Ülkeleri Örneği”. IMKB Dergisi, 5(14), 122.

Gözbaşı, O. (2010). “IMKB ile Gelişmekte Olan Ülkelerin Hisse Senedi Piyasalarının Etkileşimi: Eşbütünleşme ve Nedensellik Yaklaşımı”. Erciyes Üniversitesi İktisadi ve İdari Bilimler Fakültesi Dergisi, 35, 99-118.

Hatemi-J, A. (2008). "Tests for Cointegration with Two Unknown Regime Shifts with an Application to Financial Market Integration". Empirical Economics, 35, 497-505.

İbicioğlu, M. ve Kapusuzoğlu, A. (2011). "IMKB İle Avrupa Birliği Üyesi Akdeniz Ülkelerinin Hisse Senedi Piyasalarının Entegrasyonunun Ampirik Analizi”. Anadolu Üniversitesi Sosyal Bilimler Dergisi, 11(3), 85-102.

İpekten, O. B. ve Aksu, H. (2009). "Alternatif Yabancı Yatırım Araçlarının İMKB İndeksi Üzerine Etkisi”. Atatürk Üniversitesi Sosyal Bilimler Enstitüsü Dergisi, 13(1), 413-423.

Kasman, A., Vardar, G., Okan, B. ve Aksoy, G. (2009). "The Turkish Stock Market Integration with Developed and Emerging Countries' Stock Markets: Evidence from Cointegration Tests with and without Regime Shifts". Review of Middle East Economics and Finance, 5(1),126.

Keskin Benli, Y. (2014). "Türkiye Borsasının Gelişmekte Olan Ülkeler Borsaları İle Eşbütünleşme Analizi”. Yönetim ve Ekonomi Araştırmaları Dergisi, 23, 18-32.

Korkmaz, T., Zaman, S. ve Çevik, E.İ. (2009). "İMKB ile Uluslararası Hisse Senedi Piyasaları Arasındaki Entegrasyon İlişkisinin Yapısal Kırılma Testleri ile Analizi”. Akdeniz I.I.I.B.F. Dergisi, 17, 40-71.

Küçükkaya, E. (2009). "Diversification Benefits of including Turkish and US Stocks in a Portfolio". The International Journal of Economic and Social Research, 5(2), 1-11.

Kwiatkowski, D., Phillips, P.C.B., Schmidt, P. ve Shin, Y. (1992). "Testing the Null of Stationarity against the Alternative of a Unit Root: How Sure are We that Economic Time Series Have a Unit Root?". Journal of Econometrics, 54(1), 159-178.

Lee, J. ve Strazicich, M. C. (2003). "Minimum Lagrange Multiplier Unit Root Test With Two Structural Breaks". The Review of Economics and Statistics. 85(4), 1082-1089. 
Ş. Özşahin / Yükselen Piyasa Ekonomilerinde Menkul Kiymetler Borsalarının Entegrasyonu: Türkiye ve BRICS Ülkeleri Üzerine Çoklu Yapısal Kırllmalı Eş-bütünleşme Analizi

Maki, D. (2012). "Tests For Cointegration Allowing For an Unknown Number of Breaks". Economic Modelling. 29(5), 2011-2015.

Malatyalı, N. K. (1998). "Seçilmiş Borsa Endeks Getirileri Arasındaki Koentegrasyon İlişkileri Üzerine Bir Araştırma". IMKB Dergisi, 2(7-8), 23-34.

Marashdeh, H. (2005). Stock market integration in the MENA region: an application of the ARDL bounds testing approach. Working Paper 05-27, Department of Economics, University of Wollongong, 2005.

Maneschiold, P. (2005). "International Diversification Benefits between US, Turkish and Egyptian Stock Markets". Review of Middle East Economics and Finance, 3(2), 115-133.

Ng, S. ve Perron, P. (2001). "Lag Length Selection and the Construction of Unit Root Tests with Good Size and Power". Econometrica, 69, 1519-1554.

Perron, P. (1989). "The Great Crash, the Oil Price Shock and The Unit Root Hypothesis". Econometrica, 57, 1361-1401.

Perron, P. (1990). "Testing for a Unit Root in a Time Series with a Changing Mean. Journal of Business \& Economic Statistics, 8, 153-162.

Perron, P. ve Rodriguez, G.H. (2003). "GLS Detrending, Efficient Unit Root Tests and Structural Change". Journal of Econometrics, 115, 1-27.

Phillips, P.C.B. ve Perron, P. (1988). "Testing for a Unit Root in Time Series Regression". Biometrika, 75, 335-346.

Samırkaş, M.C. ve Düzakın, H. (2013). "İstanbul Menkul Kıymetler Borsasının Avrasya Borsaları İle Entegrasyonu". Akademik Bakış Dergisi, 35, 1-19.

Schmukler, S.L. (2008). "The Benefits and Risks of Globalization: Challenges for Developing Countries". (Editör: Joseph Stiglitz ve Jose Antonio Ocampo). Capital Market Liberalization and Development. Oxford: Oxford University Press, 48-73.

Sevüktekin, M. ve Nargeleçekenler, M. (2008). "Türkiye ve Amerika'daki Hisse Senedi Piyasaları Arasındaki Dinamik İlişkinin Belirlenmesi”. Finans Politik \& Ekonomik Yorumlar, 45(520), 15-22.

Vuran, B. (2010). "IMKB 100 Endeksinin Uluslararası Hisse Senedi Endeksleri ile İlişkisinin Eşbütünleşim Analizi ile Belirlenmesi”. İstanbul Üniversitesi İsletme Fakültesi Dergisi, 39(1), 154-168.

Yılancı V. ve Öztürk, Z.A. (2010). "Türkiye ile En Büyük Beş Büyük Ticaret Ortağının Hisse Senedi Piyasaları Arasındaki Entegrasyon İlişkisinin Analizi: Yapısal Kırılmalı Birim Kök ve Eşbütünleşme Analizi”. Erciyes Üniversitesi İ̈BF Dergisi, 36, 261-279.

Yıldız, A. ve Aksoy, E. (2014). "Morgan Stanley Gelişmekte Olan Borsa Endeksi ile BIST Endeksi Arasındaki Eşbütünleşme İlişkisinin Analiz Edilmesi”. Atatürk Üniversitesi İktisadi ve İdari Bilimler Dergisi, 28(2), 1-23.

Zivot, E. ve Andrews, D.W.K. (1992). "Further Evidence on the Great Crash, the Oil Price Shock and the Unit Root Hypothesis”. Journal of Business \& Economic Statistics, 10, 251-270.

\section{SUMMARY}

Following the removal of the restrictions on the cross-border commercial transactions in the 1980s, some policies which facilitated the transition of capital to international markets was introduced. These practices, which are called financial liberalization policies, were both domestic and international. Domestic financial liberalization includes relaxing or removing the restrictions and controls over the national financial system, while international financial liberalization involves locals' engaging in activities in international financial markets and the removal of the obstacles of trading with foreign currency. Technological improvements in information and communication sectors as well as these 
developments in the financial system have contributed to the movement of capital on international scale, and thus, many financial instruments emerged and investors made risk diversification. As a result of these developments, it has been observed that capital markets which are financially more integrated have similar trends.

This study examines whether the capital markets of Turkey and BRICS countries move in the same direction in the long term. In other words, the cointegration relationship between the stock indexes is explored. For this purpose, an econometric analysis was conducted using the Morgan Stanley Capital International (MSCI) emerging markets stock indexes in US dollar for the January 2000-December 2016 period. This study differs from other studies in that it examines the long term co-movement trend of the stock indexes of Turkey and BRICS countries in the presence of multiple structural breaks. Thus, it makes a contribution to the relevant literature. The results of the co-integration test with structural breaks indicate that Turkey BIST index act together with the stock markets of four BRICS countries (except for Brazil) in the long-term. The longterm coefficient results of the FMOLS and DOLS models revealed that there has been a positive and statistically significant relationship between Turkey and Russia, India, China, South Africa stock indexes in the long term at 99\% significance level. Based on this finding, it can be said that in the long term it will not be possible to make risk diversification among the markets as the stock markets of these countries show similar trends. 